\title{
ОСОБЛИВОСТІ РОЗВИТКУ ІНВЕСТИЦІЙНОЇ ДІЯЛЬНОСТІ У СІЛЬСЬКОМУ ГОСПОДАРСТВІ УКРАЇНИ
}

Криштанович М.Ф., д-р наук 3 держ. упр., професор, Національний університет «Львівська політехніка» м. Львів, Україна

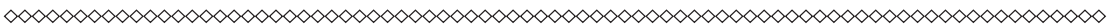

У ході дослідження проаналізовано основні чинники, щзо впливають на розвиток інвестиційної діяльності в сільському господарстві. Проаналізовано основні показники, які виражають темпи іноземного інвестування в сільськогосподарську галузь. Охарактеризовано основні показники інвестиційного розвитку сільськогосподарських підприємств, зокрема розглянуто динаміку обсягів капітальних інвестииій, частки інвестицій в агросектор в структурі ВВП, обсяг інвестииій у розрахунку на одне аграрне підприємство. Проведено дослідження та оцінювання результативності державного регулювання інвестицій у сільському господарстві, яке передбачає статистичний аналіз опорних показників.

Результатом державного регулювання інвестицій у сільському господарстві є аналіз впливу основних факторів на ефективність інвестииій. 3 метою виявлення впливу на прочес державного регулювання інвестицій у агросфері здійснено кореляційний аналіз за низкою критеріїв. Обгрунтовано перспективні напрямки удосконалення державного регулювання інвестиційної діяльності в сільському господарстві.

Система державного регулювання інвестииійної діяльності в Україні, сформована в результаті великої кількості трансформацій і реорганізацій, не є єдиною та результативною. Вона складалася з багатьох учасників, функиіі які доволі часто дублювалися, щзо в фінальному підсумку знижувало рівень управління інвестищійними 
Особливості розвитку інвестиційної діяльності у сільському господарстві Украйни процесами. Погіршення розвитку державного регулювання в сфері інвестицій, підтверджується тендениією до зниження фінансування видатків на утримання загальнодержавних установ, які здійснюють управління інвестиційними процесами в секторі економіки сільського господарства. Особливостями розвитку політики регулювання інвестиційної діяльності в сільському господарстві, також враховуються передумову зміни попиту на різні категорії агропродукиії.

За результатами аналізу сформульовано висновки щзодо особливостей впливу державного регулювання інвестиційноӥ діяльності у сільському господарстві.

Ключові слова: фактори, інвестиційна діяльність, агросектор, державне регулювання, інвестиційна привабливість.

Постановка проблеми у загальному вигляді. Розвиток інвестиційних процесів $є$ базисом розширеного відтворення в економіці. Сільське господарство, як одна 3 найбільш пріоритетних галузей в Україні, на сьогодні, як ніколи, потребує активного впровадження нових підходів у регулюванні інвестиційних процесів, забезпечення усіх необхідних умов для зростання інвестиційної привабливості. 3 огляду на це особливої актуальності набувають питання, які висвітлюють основні чинники впливу на інвестиційний розвиток сільськогосподарських підприємств, проблеми та перспективи зростання обсягів прямого іноземного інвестування у агросектор.

Аналіз останніх досліджень і публікацій. Теоретико-методичні та практичні аспекти інвестиційної діяльності у сільського господарстві, державного регулювання інвестиційних процесів в агросекторі розкрито у працях багатьох науковців, серед яких варто виділити таких як I. Безп>ята, Д. Дуков, I. Мойсеєнко, I. Назаренко, С. Халатур, В. Хопчан, П. Дем'яненка, О. Саблука, М. Левандівського, В. Ашінова, Л. Бєлоусова, Л. Смолія, А. Гайдуцький, А. Даниленко, та ін. Проте, подальшого розвитку потребують питання розробки напрямків удосконалення державної інвестиційної політики, спрямованої на зростання рівня інвестиційної привабливості аграрного сектору економіки України. 
«Public Administration and Regional Development»

https://pard.mk.ua/index.php/journal

\section{Формулювання цілей статті (постановка завдання).}

Метою статті є дослідження особливостей розвитку інвестиційної діяльності у сільському господарстві України.

Виклад основного матеріалу дослідження. Інвестиційні процеси у сільському господарстві забезпечують реалізацію принципів розширеного відтворення підприємств, формують необхідну матеріально-технічну базу для використання нових аграрних технологій. В Україні інвестиційна діяльність підприємств агросектору в значній мірі залежить від ряду чинників внутрішнього та зовнішнього середовища.

Вплив політико-правового середовища на інвестиційну діяльність в сільському господарстві виявляється через систему нормативно-правового регулювання. Підприємство не може здійснювати вплив на даний фактор. Існуюча нормативноправова база регулювання інвестиційної активності постійно вдосконалюється [2]. Варто відмітити, що вплив нормативноправового регулювання на інвестиційну діяльність підприємств агросектору в останній час має негативний відбиток, що пов'язано переважно 3 численними проблемами 3 відшкодуванням ПДВ аграріям, ускладненням процесів залучення іноземних інвестицій, відсутність правових гарантій збереження капіталу для інвесторів. Що стосується безпосередньо правового регулювання ринку сільськогосподарської сировини та дальності окремих його учасників, то найбільший пресинг на бізнес чинять фіскальні органи [1]. Для виконання сезонних робіт агропідприємства часто змушені здійснювати укладення договорів на тимчасове надання послуг фізичними особами. Державна фіскальна служба умови контрактів за наведеним принципом часто визнає як трудові відносини, що викликає ризики фіскального тиску на нормальну роботу аграрного бізнесу [4].

Досить негативно на фінансовий потенціал інвестиційної діяльності сільськогосподарських підприємств вплинули фактор бюджетно-податкового регулювання. Відповідно до змін у податкове законодавство, які спостерігалися упродовж 2017-2019 рр., умови для відшкодування ПДВ аграріям розвивалися не в кращу сторону. 
Особливості розвитку інвестиційної діяльності у сільському господарстві Украӥни

Це призводить до вимивання оборотного капіталу при експорті сільськогосподарської продукції [7].

Формування інвестиційного клімату для іноземних інвесторів в Україні є несприятливим. Процеси економічних реформ виявилися неспроможними подолати значні системні проблеми у захисті прав інвесторів. Невисокі темпи іноземного інвестування в аграрну галузь (рис. 1) не сприяють технологічному оновленню підприємств аграрної сфери.

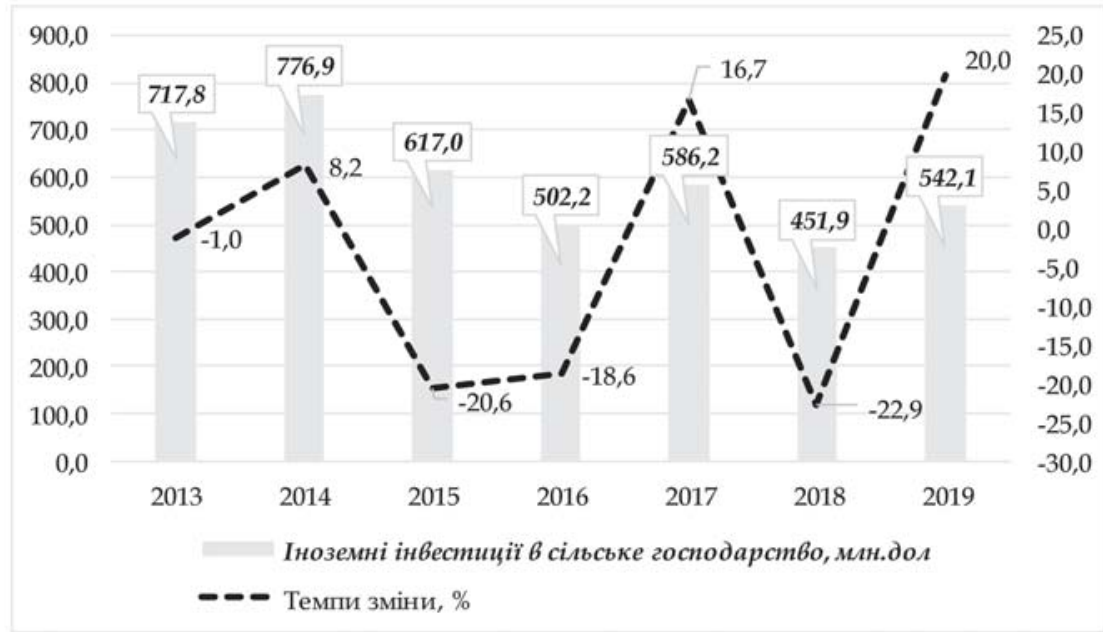

Pис. 1. Прямі іноземні інвестиції в сільське господарство України

$$
\text { y 2013-2019 рр., млрд. грн [7] }
$$

Інвестиційні проекти із залученням іноземних інвесторів, щодо яких останні претендують на одержання додаткових податкових, митних, кредитних пільг та страхових гарантій, мають сприяти створенню нових робочих місць на підприємствах, у які вкладаються інвестиції; супроводжуватися впровадженням сучасних ресурсозберігаючих та екологічно безпечних видів технологій; сприяти зниженню енергоспоживання на одиницю продукції; бути орієнтованими на найраціональніше використання сировинної бази сільського господарства. Продукція підприємства ISSN 2616-6216. Publ. upr. reg. rozvit. 2020, 8: 584-595 
«Public Administration and Regional Development»

https://pard.mk.ua/index.php/journal

3 іноземними інвестиціями має бути конкурентоспроможною на міжнародних ринках [3].

Вплив макроекономічних факторів виявляється у стабілізації валютного курсу гривні по відношенню до іноземних вільноконвертованих валют. У 2019 році, внаслідок значного укріплення курсу гривні, аграрії експортери отримали значні негативні курсові різниці, що поліпшило їх фінансовий результат (рис. 2).

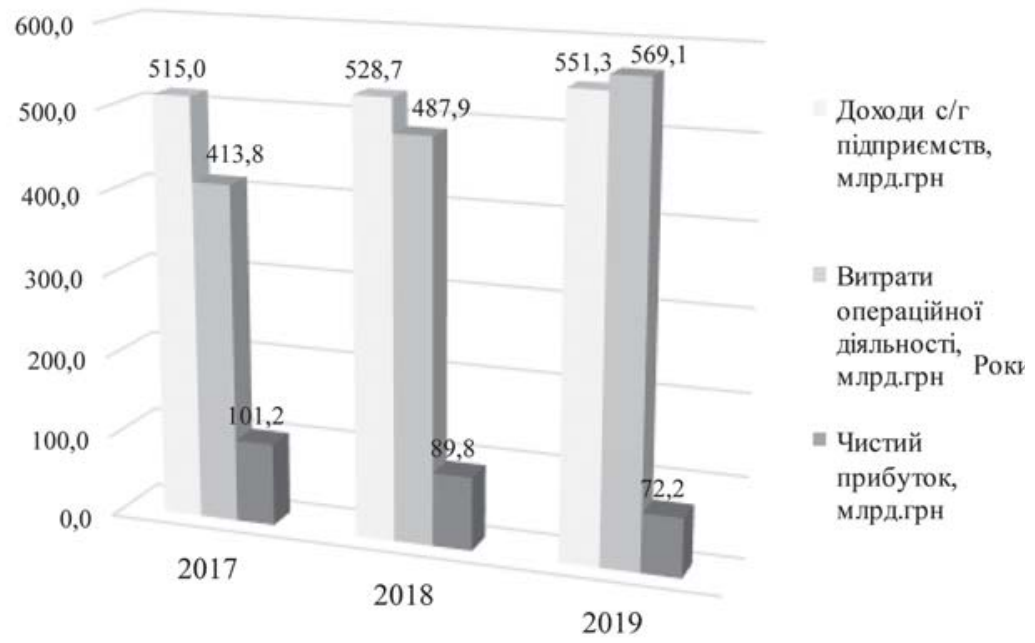

Pис. 2. Фінансові результати діяльності сільськогосподарських підприємств у 2017-2019 рр., млрд. грн

Зростання операційних витрат підприємств агросектору викликане як інфляційними процесами в економіці, так i впливом ряду інфраструктурних чинників, зокрема зміною умов транспортування агропродукції, зростання строків іiі зберігання, збільшення витрат на обробіток землі, тощо. В сучасних умовах суттєві ризики у інвестиційний потенціал аграрної сфери вносить фактор економічної кризи. У першому кварталі 2020 року (починаючи з березня), через ряд обмежувальних карантинних заходів, пов'я588 
Особливості розвитку інвестиційної діяльності у сільському господарстві Украйни заних з корона вірусною інфекцією, спостерігалися збої експортних поставок агросировини, знизився попит на неї на світових ринках.

Науково-технічні фактори позитивно впливають на формування інвестиційної діяльності в сільському господарстві. 3 одного боку, нові технології вирощування у процесах сільськогосподарських культур, зберігання зерна, організації транспортної та інформаційної логістики впливають на зростання необхідності інвестувати у сільськогосподарську галузу, а 3 іншого боку - відбувається зростання ефективності агровиробництва, що позитивно впливає на інвестиційну привабливість сільськогосподарських підприємств.

Надалі розглянемо основні показники, що характеризують процеси інвестиційної діяльності в сільському господарстві. На рис. 3 наведено динаміка обсягу капітальних інвестицій в сільське господарство та кількості сільськогосподарських підприємств за 2013-2019 pp.

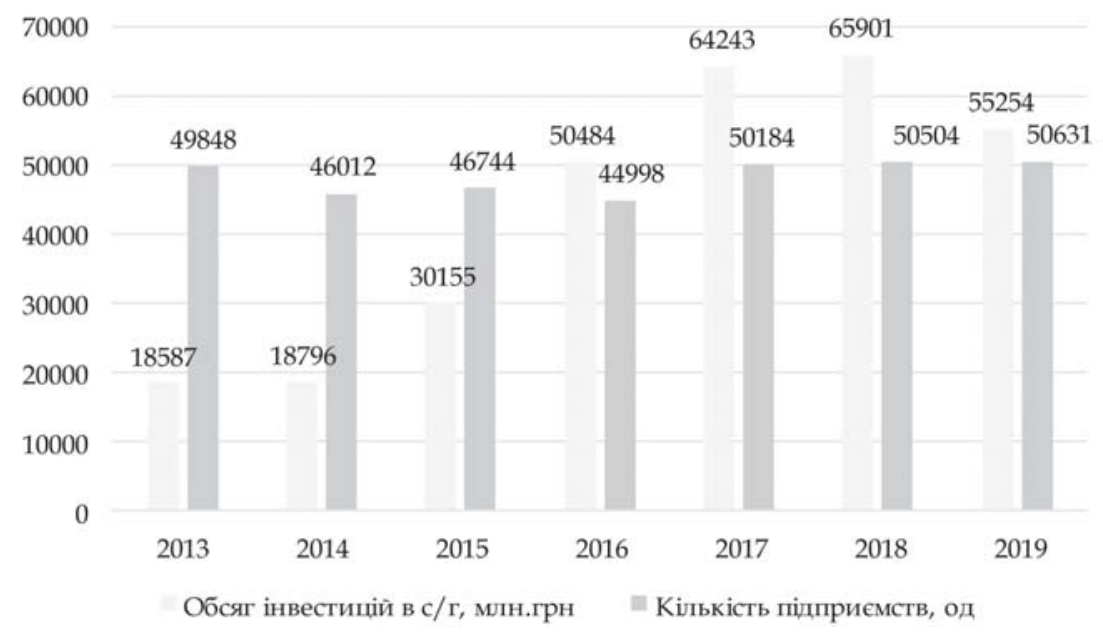

Pис. 3. Динаміка обсягу капітальних інвестииій в сільське господарство та кількості с/2 підприємств у 2013-2019 рр. [7]

Як свідчать дані рис. 3, упродовж 2013-2015 рр. можна було спостерігати зростання вартості сукупних капітальних інвестицій у ISSN 2616-6216. Publ. upr. reg. rozvit. 2020, 8: 584-595 
сільське господарство. Однак, беручи до уваги девальвацію курсу національної валюти, зростання інвестицій у період з 2013 по 2015 рр. можна розглядати як суто умовне, оскільки якщо проіндексувати таке зростання на темпи падіння курсу національної валюти, то фактично можемо отримати від'ємний приріст обсягу інвестицій. Варто також відмітити певне зростання кількості сільськогосподарських підприємств. У 2019 році в Україні було зареєстровано 50631 сільськогосподарські підприємства, що на 8\% більше, порівняно 3 аналогічним показником у 2015 році. Характеризуючи динаміку капітальних інвестицій у сільськогосподарську галузь, варто відмітити їх зниження у 2019 році на 16,2\%. Таке різке зниження інвестицій було зумовлене зменшенням обсягів капітальних вкладень у формування інфраструктури агросектору.

Важливим показниками, що виражають інтенсивність інвестиційних процесів в сільському господарстві, $€$ частка інвестицій у ВВП а обсяг інвестицій у розрахунку на 1-не с/г підприємство (рис. 4).

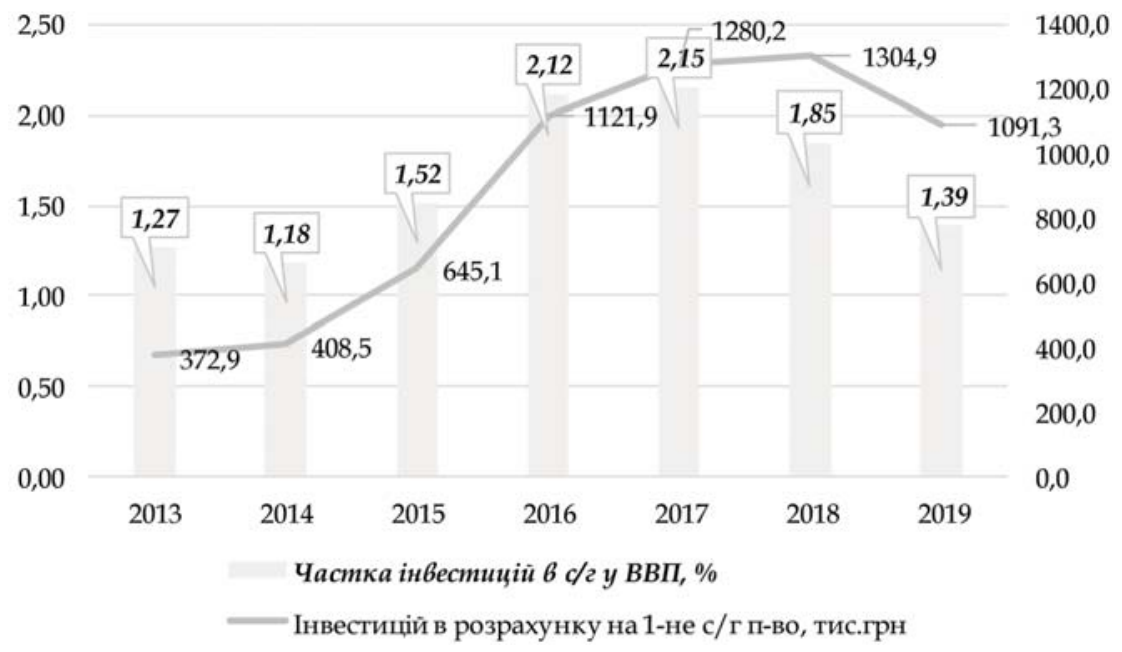

Pис. 4. Показники частки інвестииій у ВВП та обсягу інвестищзій на одне с/г підприємство у 2013-2019 рр. [7] 
Особливості розвитку інвестиційної діяльності у сільському господарстві Украӥни

Як свідчать статистичні дані, частка інвестицій у ВВП мала тенденцію до зростання у 2014-2017 рр., що пояснювалося падінням валової доданої вартості інших (відмінних від агросектору) сфер економіки на тлі економічної кризи, спричиненої війною на Сході України. Можна сказати, що процеси відновлення економіки та зростання обсягів діяльності у інших секторах господарського комплексу держави не сприяли зростанню інвестиційного потенціалу агросфери у формуванні ВВП. Така ситуація спричинена передусім рядом негативних політико-правових та фіскальних чинників, про які було сказано вище. Негативним трендом у розвитку інвестиційної діяльності в агросекторі є зниження обсягу інвестицій у розрахунку на одне підприємство агросектору. Так, якщо у 2017 році даний показник складав 1280,2 тис. грн., то у 2019 році його значення склало 1091,3 тис. грн, що на 15\% менше.

Розглянувши основні тенденції розвитку інвестиційної діяльності сільськогосподарських підприємств, варто визначити основні перспективні умови для відновлення та зростання темпів інвестиційної активності в агросекторі.

Як відзначає I. Мойсеєнко ефективність реалізації стратегії інноваційного розвитку досягається шляхом проведення виваженої економічної політики відповідно до прийнятих в установленому порядку доктрин, концепцій, стратегій і програм у політичній, економічній, соціальній, інформаційній і фінансовій сферах. На думку автора, ефективність державного регулювання інвестиційноінноваційних процесів в умовах економічної нестабільності та необхідності виходу з кризи передбачає раціональне використання інституціональних амортизаторів інвестиційного ризику державного регулювання економічних процесів детінізації економіки за рахунок податкової та митної політики, інституційного забезпечення моніторингу рівня інвестиційної безпеки та своєчасного впровадження антикризових заходів безпеки [3].

В. Хопчан зауважує, що інвестиційний клімат в Україні для іноземних інвесторів, незважаючи на певні позитивні моменти, непривабливий. Незначні обсяги іноземних вкладень, їх неефективне використання не сприяють технологічному оновленню ISSN 2616-6216. Publ. upr. reg. rozvit. 2020, 8: 584-595 
«Public Administration and Regional Development»

https://pard.mk.ua/index.php/journal

сільськогосподарського виробництва і не впливають на загальний стан галузі. На думку вченого, для залучення іноземних інвестицій необхідно насамперед розв〉язати проблеми макроекономічної стабілізації й активізувати дію усіх важелів економічного регулювання інвестиційної діяльності [6].

Доповнюючи вищесказане, С. Халатур акцентує увагу на формуванні механізмів державного стимулювання розвитку людського капіталу та створення інноваційних систем у сільському господарстві. Сильний людський капітал і динамічні сільськогосподарські інноваційні системи є критично важливими для залучення додаткових інвестицій в сільському господарстві. Політика повинна підтримувати високу якість освіти та функціонування інформаційно-консультативних послуг для підвищення людського капіталу. Вони повинні сприяти розвитку партнерських відносин між національними та міжнародними дослідженнями, краще поєднати наукові дослідження з потребами ефективного захисту прав інтелектуальної власності для створення ефективної інноваційної системи [5].

Висновки. Таким чином, проведене дослідження особливостей розвитку інвестиційної діяльності в сільському господарстві дає підстави зробити висновки про необхідність удосконалення механізмів державного регулювання інвестиційних процесів. У цьому аспекті особливої уваги потребують земельна та податкова реформи, які покликані забезпечити необхідні мінімальні умови для забезпечення достатнього рівня інвестиційної привабливості аграрної галузі України. Важливим напрямком підвищення результативності інвестиційної діяльності в сільському господарстві $\epsilon$ також стимулювання інноваційної активності, що може бути забезпечене шляхом формування інноваційної економічної політики на державному рівні.

\section{Стаття надійшла до редакції: 12.02.20}


PECULIARITIES OF DEVELOPMENT OF INVESTMENT ACTIVITY IN AGRICULTURE OF UKRAINE

Myroslav Kryshtanovych, Doctor of Science in Public Administration, Professor, Professor of the Department of Pedagogy and Innovative Education, Lviv Polytechnic National University, Lviv, Ukraine

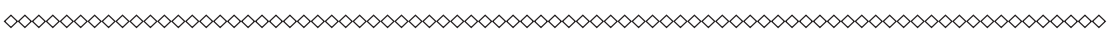

The study analyzes the main factors influencing the development of investment activities in agriculture. The main indicators that express the rate of foreign investment in the agricultural sector are analyzed. The main indicators of investment development of agricultural enterprises are characterized, in particular, the dynamics of capital investment, the share of investment in the agricultural sector in the structure of GDP, the volume of investment per agricultural enterprise are considered. A study and evaluation of the effectiveness of state regulation of investment in agriculture, which provides a statistical analysis of benchmarks.

The result of state regulation of investment in agriculture is an analysis of the impact of key factors on investment efficiency. In order to identify the impact on the process of state regulation of investments in the agricultural sector, a correlation analysis was performed according to a number of criteria. Perspective directions of improvement of state regulation of investment activity in agriculture are substantiated.

The system of state regulation of investment activity in Ukraine, formed as a result of a large number of transformations and reorganizations, is not uniform and effective. It consisted of many participants, whose functions were often duplicated, which ultimately reduced the level of investment process management. The deterioration of the development of state regulation in the field of investment is confirmed by the tendency to reduce the financing of expenditures for the maintenance of national institutions that manage investment processes in the agricultural sector. Peculiarities of the development of the policy of regulation of investment activity in agriculture also take into account the precondition of changing the demand for different categories of agricultural products. 
«Public Administration and Regional Development» https://pard.mk.ua/index.php/journal

Based on the results of the analysis, conclusions are formulated on the peculiarities of the impact of state regulation of investment activity in agriculture.

Key words: Factors, investment activity, agricultural sector, state regulation, investment attractiveness.

\section{Received: 12.02 .20}

\section{References}

1. Bezp'yata, I.V. (2016). Osoblyvosti zaluchennya inozemnykh investytsiy $\mathrm{v}$ ahrarnyy sektor ekonomiky [Features of attracting foreign investment in the agricultural sector of the economy]. Ekonomika i suspil'stvo - Economy and society, 4, $67-71$ [in Ukrainian].

2. Dukov, D.F. (2017). Napryamy udoskonalennya kompleksnoho mekhanizmu derzhavnoho upravlinnya investytsiyamy $\mathrm{v}$ rehional'nyy rozvytok [Directions for improving the integrated mechanism of state investment management in regulatory development]. Odesa [in Ukrainian].

3. Moyseyenko, I.P. (2015). Fiskal'ni aspekty derzhavnoho rehulyuvannya investytsiynoyi diyal'nosti [Fiscal aspect of state regulation of investment activity]. Naukovyy visnyk Mukachivs'koho derzhavnoho universytetu Scientific Bulletin of Mukachevo State University, 2, 243-248 [in Ukrainian].

4. Nazarenko, I.M. (2015) Analiz investytsiynoho zabezpechennya sil's'kohospodars'kykh pidpryyemstv rehioniv Ukrayiny [Analysis of investment support of agricultural enterprises in the regions of Ukraine]. Problemy ekonomiky - Economic problems, 4, 136- 143 [in Ukrainian].

5. Khalatur, S.M. (2017). Investytsiyna pryvablyvist' haluzi sil's'koho hospodarstva Ukrayiny $\mathrm{z}$ urakhuvannyam faktoriv ryzyku [Investment attractiveness of the agricultural sector of Ukraine taking into account risk factors]. Naukovyy visnyk Mizhnarodnoho humanitarnoho universytetu. Seriya : Ekonomika i menedzhment - Scientific Bulletin of the International Humanities University. Series: Economics and Management, 24(1), 59-62 [in Ukrainian].

6. Khopchan, V.M. (2015). Suchasnyy stan ta perspektyvy derzhavno- 
Особливості розвитку інвестиційної діяльності у сільському господарстві Украӥни

ho rehulyuvannya investytsiynoyi diyal'nosti v Ukrayini [Current state and prospects of state regulation of investment activity in Ukraine]. Investytsiyi: praktyka ta dosvid - Investments: practice and experience, 11, 20-23 [in Ukrainian].

7. Statystychni materialy Derzhavnoyi sluzhby statystyky Ukrayiny [Statistical materials of the State Statistics Service of Ukraine]. Retrieved from www.ukrstat.gov.ua [in Ukrainian].

8. Smoliy, L. (2009). Investytsiyne zabezpechennya ahrarnykh pidpryyemstv rehionu [Investment support of agricultural enterprises in the region]. Ekonomika APK - Economics of agro-industrial complex, 9, 65-67 [in Ukrainian].

\section{Відомості про автора / Information about the Author}

Криштанович Мирослав Франкович: Національний університет «Львівська політехніка» вул. Степана Бандери 12, м. Львів, 79016, Україна.

Myroslav Kryshtanovych: Lviv Polytechnic National University, 12, Ukraine, Stepana Bandera str., Lviv, 79016, Ukraine.

ORCID. ORG/ 0000-0003-1750-6385

\section{E-mail:mf0077@ukr.net}

